\title{
Apoptosis and Proliferation in Subcutaneous Panniculitis-Like T-Cell Lymphoma
}

\author{
Filiz Şen, M.D., George Z. Rassidakis, M.D., Dan Jones, M.D., Ph.D., L. Jeffrey Medeiros, M.D. \\ Division of Pathology and Laboratory Medicine, University of Texas, MD Anderson Cancer Center, \\ Houston, Texas
}

Subcutaneous panniculitis-like $\mathbf{T}$ cell lymphoma (SPTCL), designated recently as a distinct clinicopathologic entity in the World Health Organization Classification, is a neoplasm composed of cytotoxic T-cells that preferentially involves subcutaneous adipose tissue. Histologically, SPTCL is characterized by extensive karyorrhectic debris and tumor necrosis suggesting that apoptotic mechanisms are involved in its pathogenesis. We assessed the apoptotic index (AI) and proliferation rate (PR) of 13 cases of SPTCL by TUNEL test and Ki-67 immunostaining, respectively. We also immunohistochemically assessed for expression of BCL-2 (antiapoptosis), BAX (pro-apoptosis), and P53 and correlated the results with apoptosis and proliferation. We detected a high AI (median 8.1\%) in 11 cases of SPTCL, and 12 cases had low BCL-2 and high $\mathrm{BAX}$ expression. BCL-2/expression inversely correlated with $\mathrm{AI}(P<.001)$ and $\mathrm{BAX}(P<.001)$. We found a low $P R$ (cutoff $\geq 25 \%$ ) in eight $(61 \%)$ cases. There was an inverse correlation between $\mathrm{AI}$ and PR $(r=-.58, P=.04)$. Ten cases were assessed for P53; immunostaining results were heterogeneous but P53 expression correlated with large cell cytologic features. Our findings demonstrate that SPTCLs have a high AI that may be explained by differential expression of BCL-2 and BAX in the neoplastic cells.

KEY WORDS: Apoptosis, Immunohistochemistry, Proliferation, Subcutaneous panniculitis-like T-cell lymphoma.

Mod Pathol 2002;15(6):625-631

Copyright (C) 2002 by The United States and Canadian Academy of Pathology, Inc.

VOL. 15, NO. 6, P. 625, 2002 Printed in the U.S.A.

Date of acceptance: February 14, 2002.

Address reprint requests to: L. Jeffrey Medeiros, M.D., Division of Pathology and Laboratory Medicine, Box 72, University of Texas MD Anderson Cancer Center, 1515 Holcombe Blvd., Houston, TX 77030; e-mail: jmedeiro@mdanderson.org; fax: 713-745-0736.
Subcutaneous panniculitis-like $\mathrm{T}$ cell lymphoma (SPTCL) is a rare type of non-Hodgkin's lymphoma composed of cytotoxic T-cells, recently recognized as a distinct clinicopathological entity in the World Health Organization classification (1). Clinically, patients present with subcutaneous nodules, most commonly involving the extremities. The clinical course of patients with SPTCL is variable. Many patients have an aggressive clinical course that may respond to intensive chemotherapy regimens $(2,3)$. A subset of patients initially has an indolent clinical course $(2,4)$. Histologically, the neoplastic cells involve the subcutaneous tissue in a panniculitis-like pattern, infiltrating fibrous septae and rimming fat spaces $(1,2,4)$. Marked karyorrhectic debris and tumor necrosis are frequent in SPTCL. These findings suggest that apoptotic mechanisms may be involved in pathogenesis.

Tumor growth depends on the balance between apoptosis and proliferation. One major regulator of apoptosis is the BCL-2 family of proteins. BCL-2, the first member of this family characterized, inhibits apoptosis (5). BAX, in contrast, is another member of this family that promotes apoptosis. The ratio of BCL-2 to BAX correlates with sensitivity to apoptosis in various non-Hodgkin's lymphomas $(6,7)$ but has not been reported previously in SPTCL. Another regulator of apoptosis is the p53 gene, which encodes for a protein that induces growth arrest and apoptosis after DNA damage (8). P53 also has been shown to down-regulate BCL-2 and upregulate BAX expression in vivo and in vitro (9). Some tumor types appear to show coordinate regulation of proliferation and apoptosis by a common genetic mechanism (10). One example, in some B-cell tumors, is dysregulated activation of the MYC transcription factor that is a potent inducer of both cell proliferation and apoptosis (11). It is believed that MYC expression induces cell proliferation in a cytokine-dependent manner. Tumor cells undergo apoptosis when cytokines become limited (11).

Apoptosis and proliferation can now be assessed in fixed, paraffin-embedded tissue sections. Apoptotic index (AI) can be quantified using the terminal 
deoxynucleotidyl transferase (TdT)-mediated dUTP nick end-labeling (TUNEL) assay. Proliferation rate (PR) can be assessed using the MIB-1 antibody specific for Ki-67, a nuclear-associated proliferation antigen. Monoclonal antibodies for BCL-2, BAX, and p53 are also available.

The goal of this study was to apply these methods to a group of SPTCL cases. The results suggest that SPTCL is characterized by a high AI and that differential expression of BCL-2 and BAX may be involved in the susceptibility of SPTCL to apoptosis.

\section{MATERIALS AND METHODS}

\section{Case Selection}

Thirteen cases of SPTCL were included in this study. These cases were collected from the files of the Department of Hematopathology at our institution or were cases sent in consultation to one of us (LJM).

\section{Immunohistochemical Methods}

Most cases had been analyzed immunohistochemically to determine cell lineage using antibodies specific for CD3, CD4, CD8, CD20, and CD43. All cases were of T-cell lineage, positive for T-cell antigens and negative for CD20 (Table 1).

For this study, each case was analyzed using immunohistochemical methods and monoclonal antibodies for expression of BAX (1:40, Zymed, South San Francisco, CA), BCL-2 (1:40), p53 (1:50) and Ki-67 (1:20, DAKO, Carpinteria, CA).

All tissue sections ( 3 to $4 \mu \mathrm{m}$ thick) were deparaffinized in xylene and rehydrated in a graded series of ethanols as described previously (12). For all antibodies, heat-induced epitope retrieval was performed using a modification of a method described previously (12). Tissue sections were placed in plastic Coplin jars containing preheated target retrieval solution (DAKO), heated in a household vegetable steamer (Sunbeam-Oster, Model 4713/5710, 900 W) for 35 minutes, and allowed to cool at room temperature for at least 15 minutes. Subsequent steps of the immunostaining procedure were performed using the DAKO Autostainer (DAKO) at room temperature and included the following: blocking of endogenous peroxidase in $3 \% \mathrm{H}_{2} \mathrm{O}_{2}$ in phosphate buffered saline (PBS), pH 7.4, for 5 minutes, blocking of nonspecific protein binding sites using protein blocking solution (DAKO) for 5 minutes, incubation with the primary antibody for 1 hour, and detection using secondary anti-mouse antibody and the streptavidin-biotin-peroxidase-based $\mathrm{LSAB}+$ kit (DAKO) for 15 minutes. We used 3,3' diaminobenzidine (3,3'-diaminobenzidine) $/ \mathrm{H}_{2} \mathrm{O}_{2}$ (Biogenex, San Ramon, CA) or 3-amino-9-ethyl carbazol (AEC) as the chromogen and hematoxylin as the counterstain.

Any cytoplasmic (BCL-2, BAX) or nuclear (P53, Ki-67) staining of neoplastic cells was considered positive, irrespective of intensity. Expression levels for all antibodies were determined by counting $\geq 500$ neoplastic cells in each case. The results of CD8 and Ki-67 immunostaining were useful for localizing the neoplastic cells. Based on visual inspection of the distribution of the data, low or high expression was determined using the following cutoffs: BCL-2, $\geq 10 \%$; BAX, $\geq 10 \%$; P53, $\geq 10 \%$; and Ki-67, $\geq 25 \%$.

\section{Modified TUNEL Assay}

Formalin-fixed, paraffin-embedded tissue sections were mounted on coated slides, deparaffinized, rehydrated in a series of graded alcohols, and pretreated with proteinase $\mathrm{K}(20 \mu \mathrm{g} / \mathrm{mL})$ for 25 minutes at $37^{\circ} \mathrm{C}$. Slides were then incubated for 5 minutes in $3 \% \mathrm{H}_{2} \mathrm{O}_{2}$ in $\mathrm{PBS}$ at $\mathrm{pH} 7.4$, to block endogenous peroxidase activity. Terminal deoxynucleotide transferase (TdT; New England Biolabs, Beverly, MA), in $20 \mathrm{~mm}$ Tris-acetate ( $\mathrm{pH} 7.9$ ), $50 \mathrm{~mm}$ potassium acetate, $10 \mathrm{~mm}$ magnesium acetate, $1 \mathrm{~mm}$ DTT, $0.25 \mathrm{~mm} \mathrm{CoCl} 2$, and $24 \mu \mathrm{m}$ biotin-

TABLE 1. Summary of Clinical, Immunophenotypical, and Molecular Findings in SPTCL Cases

\begin{tabular}{|c|c|c|c|c|c|c|c|c|}
\hline $\begin{array}{c}\text { Case } \\
\text { No. }\end{array}$ & $\begin{array}{l}\text { Age } \\
\text { (y) }\end{array}$ & Sex & Anatomical Site & CD3 & CD8 & CD4 & CD43 & TCR-GR \\
\hline 1 & 20 & $\mathrm{~F}$ & Inguinal region and arm & + & + & - & + & + \\
\hline 2 & 37 & $\mathrm{~F}$ & Upper and lower extremities & ND & + & - & + & + \\
\hline 3 & 57 & $\mathrm{M}$ & Thigh & + & + & - & + & + \\
\hline 4 & 25 & $\mathrm{~F}$ & Cheek mass & + & + & - & + & + \\
\hline 5 & 56 & $\mathrm{~F}$ & Upper and lower extremities & + & + & - & ND & + \\
\hline 6 & 30 & $\mathrm{M}$ & Abdomen and axilla & ND & + & - & + & + \\
\hline 7 & 20 & $\mathrm{~F}$ & Abdomen & + & + & - & + & + \\
\hline 8 & UK & $\mathrm{F}$ & Upper extremity & + & + & - & + & + \\
\hline 9 & 41 & $\mathrm{~F}$ & Chest & + & + & - & + & + \\
\hline 10 & 76 & $\mathrm{~F}$ & Abdomen & + & ND & ND & + & ND \\
\hline 11 & 40 & M & Orbit & + & + & - & ND & ND \\
\hline 12 & 10 & $\mathrm{M}$ & Upper and lower extremities & + & + & - & + & + \\
\hline 13 & 24 & M & Neck & + & + & - & ND & + \\
\hline
\end{tabular}

SPTCL, subcutaneous panniculitis-like T-cell lymphoma; ND, not done; UK, unknown; TCR-GR, T-cell receptor gene rearrangement. 
dATP (Life Technologies, Gaithersburg, MD) was applied subsequently (15 U per slide), for 1 hour, at $37^{\circ} \mathrm{C}$. Terminal deoxynucleotide transferase catalyzes the addition of deoxynucleotides to the 3 ' hydroxy terminus of DNA molecules, including protruding, recessed, or blunt-ended double- or singlestranded DNA fragments. The TUNEL assay was modified by substituting dATP for dUTP, as described elsewhere (13). For the detection of labeled termini, streptavidin-biotin-HRP complex (LSAB+ kit) and substrate solution (both from DAKO) were used according to the manufacturer's instructions. The slides were counterstained with hematoxylin.

After quenching endogenous peroxidase activity, tissue sections of a cell pellet of K562 cells were incubated with a reaction mixture lacking TdT, which served as a negative control for each experiment.

At least 500 apoptotic nuclei and nuclear fragments were evaluated in each case. The nuclear fragments appeared as single rounded cells in a clear space or halo surrounded by contiguous cells. When more than one apoptotic fragment was seen per halo, these fragments were considered to be derived from the same cell and were counted as one. The ratio of apoptotic cells to the total number of the tumor cells within the same microscopic fields was reported as the AI. Based on the distribution of the data, $\geq 5 \%$ was used as a cutoff to distinguish between low and high AI.

\section{V.}

\section{Gene Rearrangement Analysis}

\section{Statistical Analysis}

Statistical comparisons of expression of BCL-2, BCL-2 and P53, AI, and PR were performed using the Spearman rank correlation coefficient test. Fisher's exact test was also used for parametric correlation of BCL-2, BAX, P53, AI, and PR categorical variables.

Eleven cases were analyzed for T-cell receptor (TCR) gene rearrangements; all cases for TCR $\gamma$ and one case for TCR $\beta$ and TCR $\gamma$. DNA was extracted from either paraffin-embedded or frozen tissue using standard methods. In four cases, the TCR $\gamma$ gene was assessed by a polymerase chain reaction (PCR) assay using consensus $\mathrm{V} \gamma$ and $\mathrm{J} \gamma$ primers and analyzed by denaturing gradient gel electrophoresis (14). In seven cases, the TCR $\gamma$ gene was assessed using a four-color PCR assay in combination with an automated post-PCR capillary electrophoresis method, as described elsewhere (15). In this assay, each variable-region $(\mathrm{V} \gamma)$ primer is $5^{\prime}$ end-labeled with a different fluorescent dye, allowing determination of the $V \gamma$ family involved in each TCR $\gamma$ rearrangement.
In one case, the TCR $\beta$ gene was assessed using Southern blot hybridization. DNA was digested with the EcoRI, HindIII, and BamHI restriction enzymes and analyzed using a cDNA probe specific for the constant region of the TCR $\beta$.

\section{RESULTS}

\section{Clinical and Histologic Features}

Patient age ranged from 10 to 76 years (median, $37 \mathrm{y}$ ). There were eight females and five males. The most commonly involved sites were upper and lower extremities in six, trunk in four, and head and neck region in three. Seven patients had multiple skin lesions, and six patients presented with a solitary skin tumor.

In each case, the subcutaneous tissue was infiltrated by a mixture of small to medium-sized atypical lymphoid cells, small reactive lymphocytes, and histiocytes. A predominance of large atypical lymphoid cells was present in six cases. The atypical lymphoid cells infiltrated the adipose tissue in a panniculitis-like pattern, localized in the septae between adipocytes. The neoplastic cells also rimmed fat spaces (Fig. 1). The epidermis was not involved in any case. The deep dermis was involved in two cases. Karyorrhectic debris was prominent in nine cases (Fig. 1, inset). Karyorrhectic bodies were diffusely observed in all areas, predominantly adjacent to the necrotic zones. Geographic zones of coagulation necrosis were seen in nine cases. The neoplastic infiltrate was seen adjacent to the blood vessels and infiltrated the blood vessels in some cases. However, none of these neoplasms was primarily angiocentric.

\section{Immunophenotypic and Molecular Results}

- The immunophenotype of these cases is summarized in Table 1. All 13 cases had a T-cell immunophenotype, positive for CD3 and/or CD43. In all 12 cases assessed, the neoplastic cells were positive for CD8 (Fig. 2) and negative for CD4.

The results of studies to assess clonality are summarized in Table 1 . All 11 cases assessed had clonal TCR $\gamma$ and TCR $\beta$ gene rearrangements: all 11 had TCR $\gamma$, and 1 case had TCR $\beta$. Seven cases analyzed for specific $\mathrm{V} \gamma$ family usage showed the following findings: four cases had a rearrangement that used $\mathrm{V} \gamma \mathrm{II}$, one case had rearrangements that utilized $\mathrm{V} \gamma \mathrm{II}$ and $\mathrm{V} \gamma \mathrm{IV}$, one case had three rearrangements that used $\mathrm{V} \gamma \mathrm{I}, \mathrm{V} \gamma \mathrm{II}$ and $\mathrm{V} \gamma \mathrm{IV}$, and one case had a rearrangement that used $\mathrm{V} \gamma \mathrm{IV}$.

\section{Apoptotic Index and Proliferation Rate}

The AI in these cases ranged from 1.9 to $18.4 \%$ (median $=8.1$; Table 2 ). Using a cutoff of $\geq 5 \%, 11$ cases had a high AI and 2 cases had a low AI. 




FIGURE 1. Mixed small and large atypical lymphocytes rimming fat spaces $(200 \times)$ (inset: numerous apoptotic cells and fragments; $400 \times$ both hematoxylin and eosin).

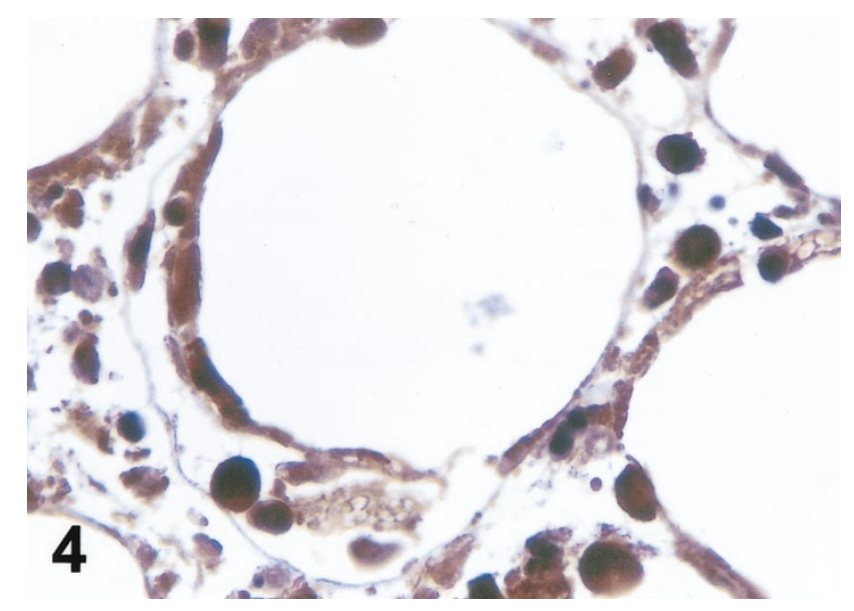

FIGURE 4. Strong intracytoplasmic expression of BAX in the cells rimming the fat spaces (immunoperoxidase staining, $1000 \times$ )

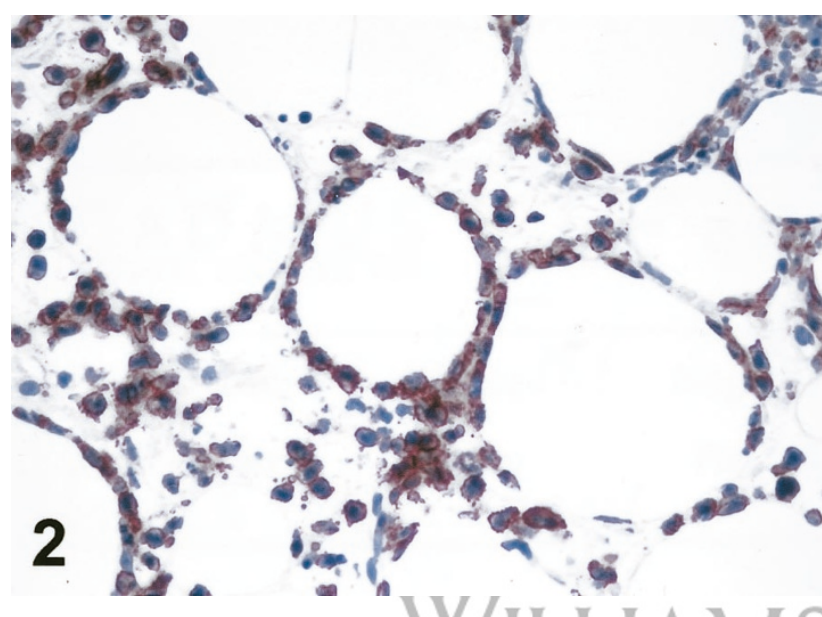
FIGURE 2. The neoplastic cells are positive for CD8
(immunoperoxidase staining, $400 \times$ )

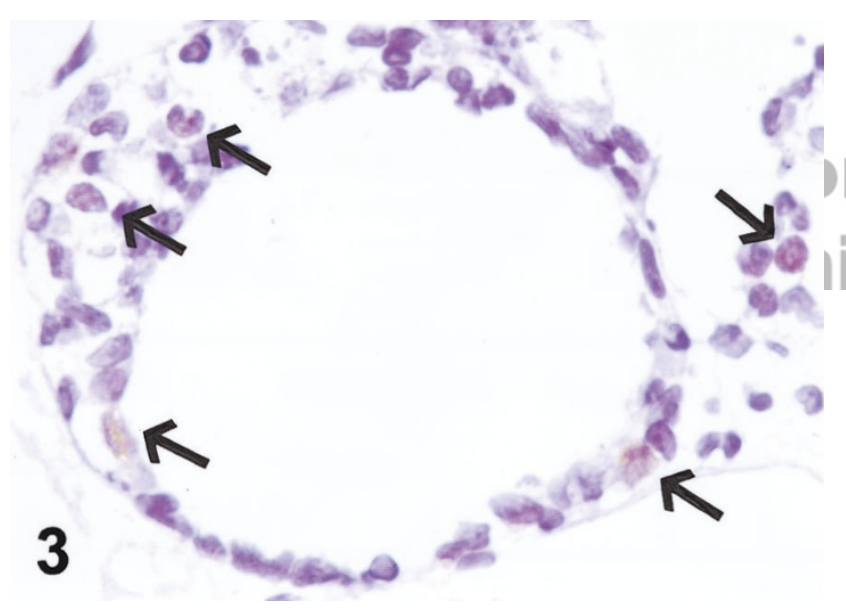

FIGURE 3. Rare reactive small lymphocytes expressing BCL-2 (Arrows; immunoperoxidase staining, 1000 $\times$ )

The PR (Ki-67 labeling index) ranged from 10 to $57.2 \%$ (median $=17.9$; Table 2; Fig. 6). Using a cutoff value of $\geq 25 \%$, 5 cases had high PR and 8 cases had low PR.

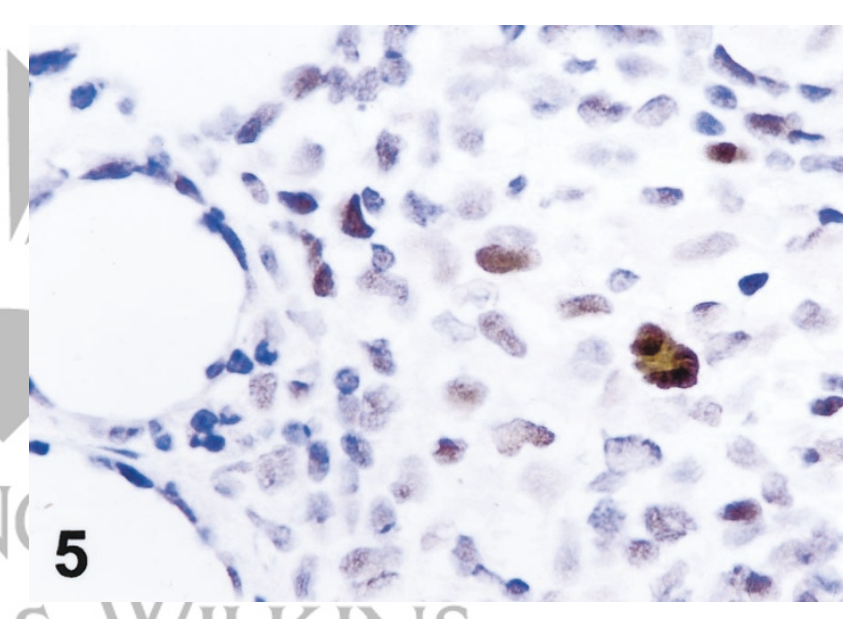

FIGURE 5. Strong P53 expression in the large neoplastic cells in comparison to weak staining in small lymphocytes (immunoperoxidase staining, $1000 \times$ ) 
TABLE 2. Summary of Apoptotic Index, Proliferation Rate, and Expression Levels of BCL-2, BAX, and p53 in SPTCL Cases

\begin{tabular}{|c|c|c|c|c|c|}
\hline Case No. & Bcl-2 (\%) & Bax (\%) & $\mathrm{AI}(\%)$ & PR (\%) & P53 (\%) \\
\hline 1 & 2.8 & 19.4 & 5.3 & 21.6 & 9.9 \\
\hline 2 & 3.0 & 16.3 & 2.3 & 34.5 & 14.8 \\
\hline 3 & 2.0 & 30.0 & 15.2 & 35.5 & 4.4 \\
\hline 4 & 2.6 & 5.3 & 9.8 & 11.3 & ND \\
\hline 5 & 2.3 & 35.0 & 9.4 & 36.0 & 25.1 \\
\hline 6 & 6.0 & 59.6 & 10.0 & 17.9 & 11.3 \\
\hline 7 & 2.6 & 36.6 & 18.4 & 10.0 & 0.6 \\
\hline 8 & 2.8 & 54.5 & 8.0 & 15.5 & 19.5 \\
\hline 9 & 5.0 & 50.0 & 16.8 & 10.4 & 0.6 \\
\hline 10 & 6.0 & 15.0 & 1.9 & 57.2 & ND \\
\hline 11 & 3.5 & 21.8 & 8.1 & 44.1 & 1.0 \\
\hline 12 & 15.0 & 78.0 & 13.8 & 15.0 & 28.0 \\
\hline 13 & 2.0 & 90.0 & 6.0 & 10.0 & ND \\
\hline
\end{tabular}

SPTCL, subcutaneous panniculitis-like T-cell lymphoma; ND, not done.

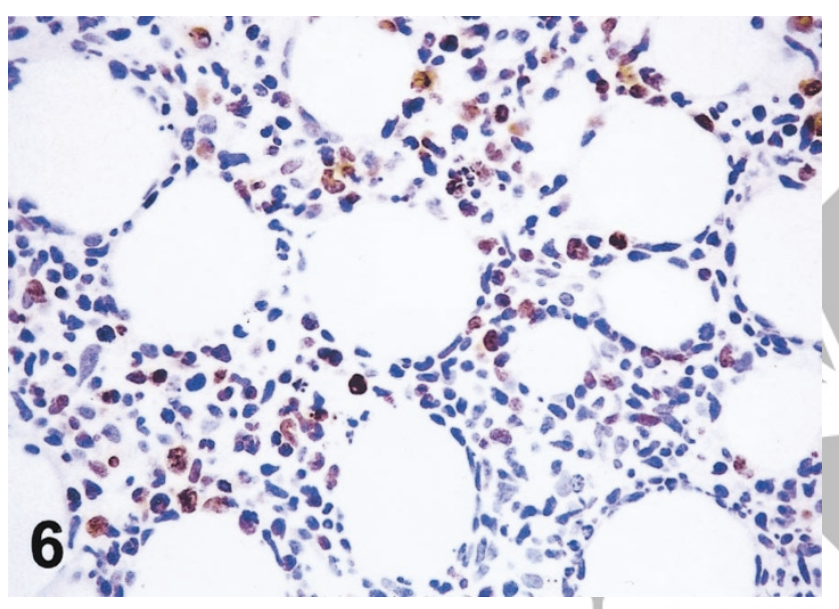

FIGURE 6. Nuclear staining with Ki-67 in virtually all neoplastic cells (immunoperoxidase staining, 200×)

Correlation of BCL-2, BAX, and P53 with the Apoptotic Index and Proliferation Rate

Box plots demonstrating the distribution of BCL-2, BAX, P53, AI, and PR are shown in Figure 7. A statistically significant inverse correlation between AI and PR $(r=-.58, P=.04)$ was noted. No correlation between other variables was found using Spearman's correlation coefficient.

Using cutoffs chosen before statistical analysis, we used Fisher's exact test and found additional statistically significant correlations. BCL-2 and BAX expression were inversely correlated $(P<.0001)$. Twelve cases with low BCL-2 expression showed high levels of BAX expression. BCL-2 expression also inversely correlated with $\mathrm{AI}(P<.001)$. Eleven cases with low BCL-2 expression had a high AI.

Apoptotic index also inversely correlated with PR $(P=.04)$. Eight cases with high AI had low PR. Two cases with low AI had high PR and three cases had both high AI and PR. No other statistically significant correlations were identified.

\section{DISCUSSION}

Tumor growth depends on a balance between cell death via apoptosis and cell proliferation (16).



FIGURE 7. Box plot summarizing the distribution of ranges of BCL-2, BAX, P53 expression, proliferation rate (PR), and apoptotic index (AI).

Based on the frequent single cell necrosis seen in SPTCL, we and others hypothesized that increased susceptibility to apoptosis may be a common feature of this tumor type (17). Here, we assessed 13 cases of SPTCL for expression of apoptotic proteins and also determined $\mathrm{AI}$ and PR.

We found that SPTCL cases have a variable but generally high AI. In our study, the median AI was $8.1 \%$, with a range up to $18.4 \%$. This is significantly higher than has been reported in many other types of non-Hodgkin's lymphoma, as seen in Table 3 (12, 18-28). For example, nodal peripheral T-cell lymphomas are reported to have an AI that ranges from 0.3 to $1.8 \%$, depending on histologic type. In general, peripheral T-cell lymphomas of large cell type have higher AI than peripheral T-cell lymphomas of small cell type $(20,27)$. Various types of small cell and large cell B-cell lymphomas of different types also show a much lower median or mean AI than in SPTCL. Low-grade tumors such as B-CLL and follicular lymphomas have an $\mathrm{AI}$ in the range of 0.09 to $0.2 \%(18,19)$ and 0.05 to $0.76 \%$, respectively $(18,19$, 21). High-grade lymphomas such as diffuse large B-cell lymphoma and Burkitt lymphoma are reported to have an AI of 0.83 to $1.68 \%$ and $1.72 \%$, respectively $(1,20,24,25)$. 
TABLE 3. Summary of Apoptotic Index (AI) and Proliferation Rate (PR) in Various Types of B- and T-Cell Non-Hodgkin's Lymphomas

\begin{tabular}{|c|c|c|}
\hline Histologic Type & $\mathrm{AI}(\%)$ & PR (\%) \\
\hline \multicolumn{3}{|l|}{ B-Cell } \\
\hline B-cell chronic lymphocytic & $0.09-0.2$ & 8.89 \\
\hline \multicolumn{3}{|l|}{$\begin{array}{l}\text { leukemia/small lymphocytic lymphoma } \\
(18,20)\end{array}$} \\
\hline \multicolumn{3}{|l|}{ Follicular lymphoma (18) } \\
\hline Grade I & 0.12 & 14.5 \\
\hline Grade II & 0.47 & 15.4 \\
\hline Follicular lymphoma (NOS) $(19,21)$ & $0.05-0.76$ & 19 \\
\hline $\begin{array}{l}\text { Low-grade B-cell MALT lymphoma } \\
\text { (stomach) }(22,23)\end{array}$ & $1.1-5.3$ & 9.1 \\
\hline Lymphoplasmacytoid lymphoma $(20,24)$ & 0.49 & 12.5 \\
\hline Mantle cell lymphoma $(20,24)$ & 0.10 & 17 \\
\hline $\begin{array}{l}\text { Diffuse large B-cell lymphoma }(20,24 \text {, } \\
25)\end{array}$ & $0.43-1.68$ & $50-54.3$ \\
\hline Burkitt lymphoma $(1,20)$ & 1.72 & $>99$ \\
\hline T-cell-rich B-cell lymphoma (26) & 2.2 & 13.0 \\
\hline \multicolumn{3}{|l|}{ T-Cell } \\
\hline $\begin{array}{l}\text { Precursor T-lymphoblastic lymphoma } \\
\text { (26) }\end{array}$ & 6.8 & 43.4 \\
\hline $\begin{array}{l}\text { Angioimmunoblastic T-cell lymphoma } \\
\text { (27) }\end{array}$ & 0.8 & 20.2 \\
\hline $\begin{array}{l}\text { Peripheral T-cell lymphoma (NOS) (18, } \\
\text { 20, 24, 26-28) }\end{array}$ & $0.3-1.81$ & -70 \\
\hline Lennert's lymphoma (26) & 2.1 & 11.4 \\
\hline \multicolumn{3}{|l|}{ Anaplastic large cell lymphoma (12) } \\
\hline ALK+ & 3.4 & 71.0 \\
\hline ALK- & 1.1 & 67.5 \\
\hline
\end{tabular}

MALT, mucosa-associated lymphoid tissue; NOS, not otherwise specified; ALK, anaplastic lymphoma kinase.

The low BCL-2 expression seen in SPTCL was strongly correlated with high BAX expression $(P<$ .001). Moreover, BCL-2 expression $(P<.001)$ correlated inversely with AI. In contrast, although BAX protein was highly expressed in SPTCL it did not correlate with $\mathrm{AI}$, nor did $\mathrm{BAX} / \mathrm{BCL}-2$ ratio correlate with high AI. This would support the notion that low BCL-2 levels are the more important factor in explaining the high apoptotic rate of SPTCL. These results are in accord with those of others who have reported that BCL-2 expression correlates inversely with AI in various types of non-Hodgkin's lymphomas (29-31).

The PR in SPTCL cases in this study was variable, ranging from 10.0 to $57.2 \%$, with a median of $17.9 \%$. This rate is lower than that reported in other types of peripheral T-cell lymphoma. In one study, Chott and colleagues (28) assessed PR in a series of nodal peripheral T-cell lymphomas. The PR in the tumors in their series ranged from 30 to $70 \%$. In general, high-grade lymphomas show high PR, with the highest rates observed in Burkitt's lymphoma, $>95 \%$, and diffuse large B-cell lymphoma and anaplastic large cell lymphoma, in the range of 55 to $71 \%$ (12). Others have shown that the PR of nonHodgkin's lymphomas correlates well with AI. Leoncini et al. (30), for example, showed that the PR correlated with AI in a number of non-Hodgkin's lymphomas of T-cell and B-cell lineage. However, SPTCL appears to be an exception to this rule; we observed an inverse correlation between $\mathrm{AI}$ and the PR.

The tumor suppressor protein P53 is another important regulator of apoptosis. P53 has been shown to be a sequence specific activator of BAX and can down-regulate BCL-2 and up-regulate BAX expression in the murine leukemia cell line M1 (9). Mice deficient in P53 show increased BCL-2 and decreased BAX protein levels. We noted increased p53 expression in the large cells of six cases of SPTCL. It is likely that tumor cells showing strong p53 expression have mutant P53 protein, as wild-type p53 has a short half-life and is not usually detected using immunohistochemical methods. It is possible that dysregulated P53 may interfere with apoptosis, but we noted no correlation between P53 and either BAX or BCL-2 expression. As with other T-cell lymphomas, dysregulated P53 expression may be a late occurrence in SPTCL that correlates with histological transformation (32).

Although not the focus of this study, we showed that all 11 cases of SPTCL assessed had clonal TCR $\gamma$ gene rearrangements. In seven cases, the TCR $\gamma$ gene was assessed using a recently described PCR assay that allows one to determine the $\mathrm{V} \gamma$ gene family used in rearrangement (15). The TCR $\gamma$ gene is relatively simple, with 11 functional variable region segments that can be segregated into four homologous families (33). Our results in seven cases suggest that the $\mathrm{V} \gamma \mathrm{II}$ family is commonly used, as six of seven SPTCL had TCR $\gamma$ rearrangements that used $\mathrm{V} \gamma \mathrm{II}$. Others have assessed the TCR $\delta$ gene in SPTCL and suggested preferential use of the V VII gene (34).

One technical problem that we encountered in assessing BAX and BCL-2 expression in SPTCL was the difficulty in distinguishing the neoplastic population from admixed reactive lymphocytes. The morphology of SPTCL is remarkable for its heterogeneous mixture of reactive lymphocytes, histiocytes, and reactive stromal cells that can obscure the neoplastic cell population. The cytologic atypia of the neoplastic cells is variable and sometimes minimal. In analysis of BCL-2 and BAX expression in routinely stained tissue sections, distinguishing of neoplastic cells from reactive lymphocytes can be difficult. We found the results of the CD8 immunostain useful in highlighting the areas most suitable for assessing expression of apoptotic proteins and apoptotic index. Alternatively, the Ki-67 immunostain is also useful for this purpose. However, reactive lymphocytes may also be CD8 positive and in the G1-S phase of the cell cycle. Thus, both the CD8 and Ki-67 immunostains overestimate the number of neoplastic cells.

In summary, the results of this study suggest that SPTCL cases have a high AI and that the suscepti- 
bility to apoptosis may be explained by differential expression of BCL-2 and BAX in the neoplastic cells.

\section{REFERENCES}

1. Jaffe ES, Ralfkier E. Subcutaneous panniculitis-like T-cell lymphoma. In: Jaffe ES, Harris NL, Stein H, Vardiman J, editors. Pathology and genetics of tumours of haematopoietic and lymphoid tissues. World Health Organization Classification of Tumours. Lyon, France: IARC Press; 2001. p. 212-3.

2. Gonzalez CL, Medeiros LJ, Braziel RM, Jaffe ES. T-cell lymphoma involving subcutaneous tissue. A clinicopathologic entity commonly associated with hemophagocytic syndrome. Am J Surg Pathol 1991;15:17-27.

3. Koizumi K, Sawada K, Nishio M, Katagiri E, Fukae J, Fukeda $\mathrm{Y}$, et al. Effective high-dose chemotherapy followed by autologous peripheral stem cell transplantation in a patient with the aggressive form of histiocytic panniculitis. Bone Marrow Transplant 1997;20:171-3.

4. Salhany KE, Macon WR, Choi JK, Elenitsas R, Lessin SR, Felgar RE, et al. Subcutaneous panniculitis-like T-cell lymphoma, clinicopathologic, immunophenotypic, and genotypic analysis of alpha/beta and gamma/delta subtypes. Am J Surg Pathol 1998;22:881-93.

5. Korsmeyer SJ, Shutter JR, Veis DJ, Merry DE, Oltvai ZN. Bcl-2/Bax: a rheostat that regulates an anti-oxidant pathway and cell death. Semin Cancer Biol 1993;4:327-32.

6. Mc Conkey D, Chandra J, Wright S, Plunkett W, McDonnell TJ, Reed JC, et al. Apoptosis sensitivity in chronic lymphocytic leukemia is determined by endogenous endonuclease content and relative expression of Bcl-2 and Bax. J Immunol 1996;156:2624-30.

7. Gascoyne RD, Krajewska M, Krajewski S, Connors JM, Reed JC. Prognostic significance of Bax protein expression in diffuse aggressive non-Hodgkin's lymphoma. Blood 1997;90:3173-8.

8. Bates S, Vousden KH. P53 in signaling checkpoint arrest or apoptosis. Curr Opin Genet Dev 1996;6:12-8.

9. Miyashita T, Krajewski S, Krajewska M, Wang HG, Lin HK, Liebermann DA, et al. Tumor suppressor p53 is a regulator of bcl-2 and bax gene expression in vitro and in vivo. Oncogene 1994;9:1799-805.

10. Hale AJ, Smith CA, Sutherland LC, Stoneman VE, Longthorne VL, Culhane AC, et al. Apoptosis: molecular regulation of cell death. Eur J Biochem 1996;236:1-26.

11. Pelengaris S, Rudolph B, Littlewood T. Action of Myc in vivo-proliferation and apoptosis. Curr Opin Genet Dev 2000;10:100-5.

12. Rassidakis GZ, Sarris AH, Herling M, Ford RJ, Cabanillas F, McDonell TJ, et al. Differential expression of BCL-2 family proteins in ALK-positive and ALK-negative anaplastic large cell lymphoma of T/null-cell lineage. Am J Pathol 2001;159:527-35.

13. Gavrieli Y, Sherman Y, Ben-Sasson SA. Identification of programmed cell death in situ via specific labeling of nuclear DNA fragmentation. J Cell Biol 1992;119:493-501.

14. Theodorou I, Delfau-Larue MH, Bigorgne C, Lahet C, Cochet G, Bagot M, et al. Cutaneous T-cell infiltrates: analysis of $\mathrm{T}$-cell receptor gamma gene rearrangement by polymerase chain reaction and denaturing gradient gel electrophoresis. Blood 1995;86:305-10.

15. Vega F, Medeiros LJ, Jones D, Abruzzo LV, Lai R, Manning J, et al. A novel four-color PCR assay to assess T-cell receptor gamma gene rearrangements in lymphoproliferative lesions. Am J Clin Pathol 2001;17-24.

16. Wyllie AH. The biology of cell death in tumours. Anticancer Res 1985;5:131-6.

17. Kumar S, Krenacs L, Medeiros LJ, Elenitoba-Johnson KS, Greiner TC, Sorbara L, et al. Subcutaneous panniculitic T-cell lymphoma is a tumor of cytotoxic T lymphocytes. Hum Pathol 1998;29:397-403.
18. Korkolopoulou P, Angelopoulou MK, Kontopidou F, Tsenga A, Patsouris E, Thomas-Tsagli E, et al. Prognostic relevance of apoptotic cell death in non-Hodgkin's lymphomas: a multivariate survival analysis including Ki67 and p53 oncoprotein expression. Histopathology 1998;33:240-7.

19. de Melo N, Matutes E, Cordone I, Morilla R, Catovsky D. Expression of Ki-67 nuclear antigen in B and T cell lymphoproliferative disorders. J Clin Pathol 1992;45:660-3.

20. Soini Y, Raunio H, Paakko P. High grade malignant nonHodgkin's lymphomas differ from low-grade lymphomas in the extent of apoptosis and their expression of bcl-2, mcl-1, bax and p53. Tumor Biol 1998;19:176-85.

21. Czader M, Mazur J, Pettersson M, Liliemark J, Stromberg M, Christensson B, et al. Prognostic significance of proliferative and apoptotic fractions in low grade follicle center cell-derived non-Hodgkin's lymphomas. Cancer 1996;77: $1180-8$.

22. Guidoboni M, Doglioni C, Laurino L, Boiocchi M, Dolcetti R. Activation of infiltrating cytotoxic T lymphocytes and lymphoma cell apoptotic rates in gastric MALT lymphomas, differences between high grade and low grade cases. Am J Pathol 1999;155:823-9.

23. Nakamura S, Akazawa K, Yao T, Tsuneyoshi M. Primary gastric lymphoma. A clinicopathologic study of 233 cases with special reference to evaluation with the MIB-1 index. Cancer 1995;76:1313-24.

24. Gerdes J, Dallenbach F, Lennert K, Lemke H, Stein H. Growth fractions in malignant non-Hodgkin's lymphomas (NHL) as determined in situ with the monoclonal antibody Ki-67. Hematol Oncol 1984;2:365-71.

25. Del Vecchio MT, Leoncini L, Buerki K, Kraft R, Megha T, Barbini $\mathrm{P}$, et al. Diffuse centrocytic and/or centroblastic malignant non-Hodgkin's lymphomas: comparison of mitotic and pyknotic (apoptotic) indices. Int J Cancer 1991; $47: 38-43$.

26. Kiberu SW, Pringle JH, Sobolewski S, Murphy P, Lauder I. Correlation between apoptosis, proliferation and bcl-2 expression in malignant non-Hodgkin's lymphoma. J Clin Pathol 1996;49:268-72.

27. Yamaguchi S, Kitagawa M, Inoue M, Tomizawa N, Kamiyama R, Hirokawa K. Cell dynamics and expression of tumor necrosis factor (TNF)- $\alpha$, interleukin-6, and TNF receptors in angioimmunoblastic lymphadenopathy-type $\mathrm{T}$ cell lymphoma. Exp Mol Pathol 2000;68:85-94.

28. Chott A, Augustin I, Wrba F, Hanak H, Ohlinger W, Radaszkiewicz T. Peripheral T-cell lymphomas: a clinicopathologic study of 75 cases. Hum Pathol 1990;21:1117-25.

29. Spina D, Leoncini L, Del Vecchio MT, Megha T, Minacci C, Poggi SA, et al. Low versus high cell turnover in diffusely growing non-Hodgkin's lymphomas. J Pathol 1995;177: $335-41$.

30. Leoncini L, Del Vecchio MT, Megha T, Barbini P, Galieni P, Pileri S, et al. Correlations between apoptotic and proliferative indices in malignant non-Hodgkin's lymphomas. Am J Pathol 1993;142:755-63.

31. Gisbertz IAM, Schouten HC, Bot FJ, Arends JW. Proliferation and apoptosis in primary gastric B-cell non-Hodgkin's lymphoma. Histopathology 1997;30:152-9.

32. Jones D, Weissmann DJ, Kraus MD, Hasserjian RP, Shahsafaei A, Dorfman DM. Recurrences in nodal T-cell lymphoma. Changes in histologic appearance and immunophenotype over the course of disease. Am J Clin Pathol 2000;114:438-47.

33. Lefranc MP, Rabbitts TH. The human T-cell receptor gamma (TRG) genes. Trends Biochem Sci 1989;14:214-8.

34. Przybylski GK, Wu H, Macon WR, Finan J, Leonard DG, Felgar RE, et al. Hepatosplenic and subcutaneous panniculitis-like gamma/delta T cell lymphomas are derived from different $\mathrm{V}$ delta subsets of gamma/delta $\mathrm{T}$ lymphocytes. J Mol Diagn 2000;2:11-9. 